\title{
Nutritional Status of School Children (6-12 years) in Deodar Taluka - Gujarat
}

\author{
Nayna P. Raval*, I. N. Patel, Kundan Joshi and Surabhi Singh
}

Foods \& Nutrition, SDAU, Gujarat, India

*Corresponding author

\section{A B S T R A C T}

\begin{tabular}{|l|}
\hline Ke y w o r d s \\
School children, \\
$\begin{array}{l}\text { Nutritional status, } \\
\text { Malnutrition }\end{array}$ \\
\hline Article Info \\
\hline $\begin{array}{l}\text { Accepted: } \\
\text { 26 July 2020 } \\
\text { Available Online: } \\
\text { 10 August } 2020\end{array}$ \\
\hline
\end{tabular}

In India, factors pertaining to poverty, illiteracy, women's workload and poor decision making traditional beliefs and practices and men's attitude towards child care contribute to malnutrition and eventually to maternal and child deaths. At location and sub-location levels, lack of basic services, resource mobilization and administrative structures that are unresponsive to the community needs further aggravate the situation of malnutrition. The objective of research was to study the personal, socio-economic characteristics and nutritional status of primary school children. 10 villages of the Deoder Taluka were selected randomly for conducting the research and from each selected school 30 children (both boys and girls) were selected by random sampling technique. Hence, a sample of 300 rural primary school children was drawn. The data shows 51 per cent of children were having low weight (BMI 18.5-20.0) followed by 40.33 per cent of children were having normal weight (BMI between20.0-25.0). Socio-economic status of majority of the families was low. They were undernourished or had moderate level of malnutrition.

\section{Introduction}

"Today's children are tomorrow's citizens." Children are considered to be the backbone of the nation. India has one of the largest population of school going children where a majority of them do not have access to essential requirement of nutrition, health care and learning opportunities.

In India, factors pertaining to poverty, illiteracy, women's workload and poor decision making opportunities, traditional beliefs and practices and men's attitude towards child care contribute to malnutrition and eventually to maternal and child deaths. At location and sub-location levels, lack of basic services, resource mobilization and administrative structures that are unresponsive to the community needs further aggravate the situation of malnutrition.

Low socio-economic conditions are the most important factor that helps in increasing the percentage of malnutrition among school children in rural areas. So implantation of good feeding habits and to get a safe food in primary school children and all surrounding persons through nutritional education is very crucial (John and Lewis et al., 2000). 
The school going children, 6 to 12 years old, is a period of steady physical growth. The average gain in weight during this period is about 3 to $3.5 \mathrm{~kg}$ per year and in height approximately $6 \mathrm{~cm}$ added each year. This is the prime time to build up body stores of nutrients in preparation for rapid growth of adolescence. So, the school age period is nutritionally significant. This investigation was conducted with following objectives include to study the personal and socioeconomic characteristics of primary school children and also to study the nutritional status of primary school children.

Chamar (2015) conducted the study for assessment of nutritional status of school children and discovered that from total of 350 children, 51.71 per cent children belonged to normal nutritional status whereas as 28.57 and 12.28 per cent exhibited wasted and stunted (short and long duration malnutrition) followed by 7.42 per cent children belonged to wasted and stunted (current and long duration malnutrition).

Fifty per cent children belonged to medium socio economic status, while 27.42 and 22.28 per cent belonged to low and high socio economic status. This finding of the study showed that socio economic status of children increased, of well-nourished children increased and under nourished children decreased.

Sati and Dahiya (2012) reported that the situation of malnutrition in children is also grave in Haryana as according to National Family Health Survey (2005-2006), the prevalence of wasted, stunted and underweight children was $19.1 \%, 45.7 \%$ and $39.5 \%$ respectively.

Kumawat et al., (2016) conducted a study on 720 school children in the age group 6 to 14 years from urban and rural areas in Bikaner district of Rajasthan from July 2014-
December 2014 with the objective to assess prevalence and types of malnutrition. The study tool used was a pre-tested questionnaire. They found that prevalence of underweight and overweight (based on weight for age) was $19.72 \%$ and $0.70 \%$ respectively. $9.86 \%$ of the study population was found to be stunted. Thinness and obesity (based on BMI-for-age) was seen in $22.22 \%$ and $1.95 \%$ children. Hence overall prevalence of malnutrition was found to be $24.17 \%$. Around one fourth of study population is affected from malnutrition which calls for urgent and prompt action in term of Primordial and Primary prevention.

Rahaman et al., (2019) the stage also determines their life time health, strength and intellectual vitality. From literature, it is found that the health and nutritional status of school children are very poor especially in rural areas because of low socioeconomic status, pattern of father's occupation and low education of parents. Apart from that nutrition education must be included from pre-primary to all education system Tribal children were more under nourished, so healthcare facility and nutrition supplement should be specialized for this group of children.

\section{Materials and Methods}

The present study was conducted in the rural areas of Deodar Taluka of Banaskantha District. Ten villages were selected randomly for conducting the study. Deodar Taluka has been identified as a socially and educationally backward Taluka, Hence it was selected for conducting the study. Deodar taluka consists of 72 villages, out of which 10 villages were selected randomly for conducting the study. During the period of investigation, list of primary school children in the age group of 6 to 12 years was obtained from school of randomly selected 10 villages of the Deoder Taluka and from each selected school 30 children (both boys and girls) were selected 
by random sampling technique. Hence, a sample of 300 rural primary school children was drawn. A pre-structured teacher made interview schedule was developed and used for the collection of data.

The data were collected through personal interview technique for socio-economic characteristics and dietary pattern. Whereas, data on anthropometric measurement were collected by using standard techniques.

\section{Results and Discussion}

\section{Personal and socio-economic characteristics of primary school children}

Socio-economic background of the family is a powerful determinant of health and wellbeing of its members especially children (NNMB, 2000) (Table 1).

Age wise distribution showed that 46 per cent children belonged to the age group 6 to 8 years, followed by the of age group 8 to 10 years (42.76 per cent) and remaining 11.33 per cent were in age group10 to 12 years. Sex wise distribution of the children showed 50.67 per cent boys and 49.33 per cent girls.

Similar gender composition of the study population was also observed by Singh et al., (2009) in Jhansi city and found that sex proportion was $52.98 \%$ male and $47.02 \%$ female. This shows higher boys population than girls.

The data of the present evaluation, that majority ( 78 per cent) of families were having medium size family up to 5 to 8 members, followed by small size (16.7 per cent) and very less from large size 5.3 per cent respectively.

The data shows that majority ( 80.00 per cent) of the respondents family were having medium annual income, 11.67 per cent of respondent's family were having low annual income and very few 08.33 per cent families were having high annual income, respectively.

Table 2 showed that maximum of mothers 45.40 per cent were Primary level educated and one group of the mothers were having education level till Secondary 29.03 per cent, some of mothers were Illiterate 22.7 per cent, and only few mothers $(1.3 \%)$ were educated up to Higher Secondary and graduation level. It reveals that people were less aware about the importance of education.

It is evident from the Table 2 that 55.00 per cent of the respondent's mothers were engaged in the occupation of farming cum home maker and 39.67 per cent of the mothers were engaged in animal husbandry cum homemaker. Very few 2.66 per cent, 2.0 per cent and 0.67 per cent of respondent's mothers were, home maker, working/service and home scale business, respectively. Thus, they totally depend upon local existing occupation like animal husbandry, agricultural and household works. 38.0 per cent children's father were having education up to primary level and 29.0 per cent were secondary educated, 20 per cent of father were illiterate, 9.0 per cent were higher Secondary and very few of the fathers 4.0 per cent were educated up to graduate level. Present findings showed that people are less aware about the importance of education.

Results in Table 2 showed that 65.33 per cent of the respondent's father, that majority 78 per cent of families were of medium size having up to 5 to 8 members, followed by small size 16.7 per cent and very less from large size 5.3 per cent respectively were engaged in farming and followed by 18.00 per cent those were businessmen, also few of them 9.67 per cent were doing labor work and 
7.00 per cent were doing service. Moreover, it shows that their education levels as well as social and economic conditions were not good.

Nutritional status of primary school children

The data presented in Table 2 showed that 51 per cent of children were having low weight (BMI 18.5-20.0) followed by 40.33 per cent of children were having normal weight (BMI between20.0-25.0).

Chronic energy deficiency grade I (BMI 17.0 - 18.50) was found in 6. 33 per cent of the children and chronic energy deficiency grade II (BMI 16.0-17.0) was found in 1.67 per cent of the children. Very few $(0.67 \%)$ of the children were having obese grade I (BMI 25.0-30.0). Kumawat et al., (2016) conducted a study on 720 school children of Bikaner, Rajasthan and found that thinness and obesity (based on BMI-for-age) was seen in 22.22 per cent and 1.95 per cent children respectively. Hence, overall prevalence of malnutrition was found 24.17 per cent.

The data shows the classification of primary school children according to Indian Academy of Pediatrics (IAP) classification of weight for age. Results revealed that 65 per cent of the respondents were in the normal category and having normal weight. Grade I category which indicates mild malnutrition was found in 16.33 per cent respondents. Grade II category which indicates moderate malnutrition was seen in 16.33 per cent respondents. Grade III category which indicates severe malnutrition was seen in 2.34 per cent of the respondents.

Table.1 Personal and socio-economic characteristics of primary school children

\begin{tabular}{|c|c|c|c|c|}
\hline \multirow[b]{2}{*}{ Age } & \multicolumn{2}{|c|}{ Boys } & \multicolumn{2}{|c|}{ Girls } \\
\hline & $\mathbf{f}$ & $\%$ & $\mathbf{f}$ & $\%$ \\
\hline $6-8$ & 68 & 44.74 & 70 & 47.29 \\
\hline 8-10 & 65 & 42.76 & 63 & 42.57 \\
\hline $10-12$ & 19 & 12.50 & 15 & 10.14 \\
\hline sex & $\mathbf{f}$ & $\%$ & $\mathbf{f}$ & $\%$ \\
\hline--- & 152 & 50.67 & 148 & 49.33 \\
\hline Size of family & $\mathbf{f}$ & $\%$ & $\mathbf{f}$ & $\%$ \\
\hline Small (up to 4 members) & 023 & 15.13 & 027 & 18.24 \\
\hline Medium (5-8 members) & 123 & 80.92 & 111 & 75.00 \\
\hline Large (above 8 members) & 006 & 03.95 & 010 & 06.76 \\
\hline Annual income & $\mathbf{f}$ & $\%$ & $\mathbf{f}$ & $\%$ \\
\hline Low (below 50,000) & 019 & 12.50 & 016 & 10.81 \\
\hline $\begin{array}{l}\text { Medium }(50,000 \text { to } \\
80,000)\end{array}$ & 120 & 78.95 & 120 & 81.08 \\
\hline High (above 80,000) & 013 & 08.55 & 12 & 08.11 \\
\hline
\end{tabular}


Table.2 Distribution of parents according to their level of education and occupation

\begin{tabular}{|l|c|c|}
\hline Education of Mother & f & $\%$ \\
\hline Illiterate & 068 & $\mathbf{2 2 . 7 0}$ \\
\hline Primary & 136 & $\mathbf{4 5 . 4 0}$ \\
\hline Secondary & 088 & $\mathbf{2 9 . 3 0}$ \\
\hline Higher Secondary & 004 & $\mathbf{0 1 . 3 0}$ \\
\hline Graduate & 004 & $\mathbf{0 1 . 3 0}$ \\
\hline Occupation of mother & $\mathbf{f}$ & $\mathbf{\%}$ \\
\hline Farming cum homemaker & 165 & $\mathbf{5 5 . 0 0}$ \\
\hline homemaker & 008 & $\mathbf{0 2 . 6 6}$ \\
\hline Animal Husbandry cum homemaker & 119 & $\mathbf{3 9 . 6 7}$ \\
\hline Working / Service & 006 & $\mathbf{0 2 . 0 0}$ \\
\hline Any other (Home scale Business ) & 002 & $\mathbf{0 0 . 6 7}$ \\
\hline Education of father & $\mathbf{f}$ & $\mathbf{\%}$ \\
\hline Illiterate & 060 & $\mathbf{2 0 . 0 0}$ \\
\hline Primary & 114 & $\mathbf{3 8 . 0 0}$ \\
\hline Secondary & 087 & $\mathbf{2 9 . 0 0}$ \\
\hline Higher Secondary & 027 & $\mathbf{0 9 . 0 0}$ \\
\hline Graduate & 012 & $\mathbf{0 4 . 0 0}$ \\
\hline Occupation of mother & $\mathbf{f}$ & $\mathbf{\%}$ \\
\hline Farming & 196 & $\mathbf{6 5 . 3 3}$ \\
\hline Service & 021 & $\mathbf{0 7 . 0 0}$ \\
\hline Business & 054 & $\mathbf{1 8 . 0 0}$ \\
\hline Labor & $\mathbf{0 2 9}$ & $\mathbf{0 9 . 6 7}$ \\
\hline
\end{tabular}

Table.3 Distribution of primary school children according to Body Mass Index (BMI) classification and Academy of Pediatrics classification

\begin{tabular}{|c|c|c|c|c|c|c|}
\hline \multirow{2}{*}{$\begin{array}{l}\text { BMI } \\
\left(\mathrm{kg} / \mathrm{m}^{2}\right)\end{array}$} & \multicolumn{2}{|c|}{ Boy } & \multicolumn{2}{|c|}{ Girls } & \multicolumn{2}{|c|}{ Total } \\
\hline & $\mathbf{f}$ & $\%$ & f & $\%$ & f & $\%$ \\
\hline CED Grade-II Moderate (16.0-17.0) & 03 & 01.97 & 02 & 01.35 & 005 & 01.67 \\
\hline $\begin{array}{l}\text { CED Grade-I Mild } \\
(17.0-18.50)\end{array}$ & 09 & 05.92 & 10 & 06.76 & 019 & 06.33 \\
\hline Low weight (18.5-20.0) & 79 & 51.97 & 74 & 50.00 & 153 & 51.00 \\
\hline $\operatorname{Normal}(20.0-25.0)$ & 61 & 40.14 & 60 & 40.54 & 121 & 40.33 \\
\hline Obese grade I (25.0-30.0) & 00 & 00 & 02 & 01.35 & 02 & 00.67 \\
\hline $\begin{array}{l}\text { Academy of Pediatrics } \\
\text { (IAP) classification }\end{array}$ & \multicolumn{2}{|c|}{ Boy } & \multicolumn{2}{|c|}{ Girls } & \multicolumn{2}{|c|}{ Total } \\
\hline $\begin{array}{l}\text { Stage of Malnutrition } \\
\text { Weight for age }(\%)\end{array}$ & $\mathbf{f}$ & $\%$ & f & $\%$ & f & $\%$ \\
\hline Normal $(>80 \%)$ & 97 & 63.82 & 98 & 66.22 & 195 & 65.00 \\
\hline Grade I (70-80\%) & 24 & 15.78 & 25 & 16.89 & 049 & 16.33 \\
\hline Grade II $(60-70 \%)$ & 26 & 17.11 & 23 & 15.54 & 049 & 16.33 \\
\hline
\end{tabular}

Source - WHO (2007), IAP (1972) 
Table.4 Distribution of primary school children according to Anthropometric measurements

\begin{tabular}{|c|c|c|c|c|c|c|}
\hline \multirow[t]{2}{*}{ Height (cm) } & \multicolumn{2}{|c|}{ Boys } & \multicolumn{2}{|c|}{ Girls } & \multicolumn{2}{|c|}{ Total } \\
\hline & $\mathbf{f}$ & $\%$ & $\mathbf{f}$ & $\%$ & $\mathbf{f}$ & $\%$ \\
\hline$<100$ & 001 & 00.66 & 001 & 00.66 & 002 & 00.67 \\
\hline $100-140$ & 119 & 78.29 & 121 & 81.76 & 240 & 80.00 \\
\hline$>140$ & 032 & 21.05 & 026 & 17.58 & 058 & 19.33 \\
\hline \multirow[t]{2}{*}{ Weight (kg) } & \multicolumn{2}{|c|}{ Boys } & \multicolumn{2}{|c|}{ Girls } & \multicolumn{2}{|c|}{ Total } \\
\hline & $\mathbf{f}$ & $\%$ & $\mathbf{f}$ & $\%$ & $\mathbf{f}$ & $\%$ \\
\hline$<15$ & 002 & 01.32 & - & - & 002 & 00.67 \\
\hline $15-30$ & 138 & 90.79 & 122 & 82.43 & 260 & 86.66 \\
\hline$>\mathbf{3 0}$ & 012 & 07.89 & 026 & 17.57 & 038 & 12.67 \\
\hline \multirow{2}{*}{$\begin{array}{c}\text { Mid upper arm } \\
\text { circumference }(\mathbf{c m})\end{array}$} & \multicolumn{2}{|c|}{ Boys } & \multicolumn{2}{|c|}{ Girls } & \multicolumn{2}{|c|}{ Total } \\
\hline & f & $\%$ & f & $\%$ & $\mathbf{f}$ & $\%$ \\
\hline$<15$ & 31 & 20.39 & 30 & 20.27 & 061 & 20.33 \\
\hline $15-20$ & 99 & 65.14 & 103 & 69.59 & 202 & 67.33 \\
\hline$>20$ & 22 & 14.47 & 15 & 10.14 & 037 & 12.34 \\
\hline Total & 152 & 100 & 148 & 100 & 300 & 100.00 \\
\hline \multirow{2}{*}{$\begin{array}{c}\text { Chest circumference } \\
(\mathbf{c m})\end{array}$} & \multicolumn{2}{|c|}{ Boys } & \multicolumn{2}{|c|}{ Girls } & \multicolumn{2}{|c|}{ Total } \\
\hline & f & $\%$ & f & $\%$ & f & $\%$ \\
\hline$<50$ & 024 & 15.79 & 010 & 06.76 & 034 & 11.33 \\
\hline $50-70$ & 127 & 83.55 & 138 & 93.24 & 265 & 88.34 \\
\hline$>70$ & 001 & 00.66 & - & - & 001 & 00.33 \\
\hline Total & 152 & 100 & 148 & 100 & 300 & 100.00 \\
\hline \multirow{2}{*}{$\begin{array}{c}\text { Head circumference } \\
(\mathbf{c m})\end{array}$} & \multicolumn{2}{|c|}{ Boys } & \multicolumn{2}{|c|}{ Girls } & \multicolumn{2}{|c|}{ Total } \\
\hline & f & $\%$ & f & $\%$ & $\mathbf{f}$ & $\%$ \\
\hline$<45$ & 002 & 01.32 & 002 & 01.35 & 004 & 01.33 \\
\hline $45-50$ & 120 & 78.95 & 059 & 39.87 & 179 & 59.67 \\
\hline$>\mathbf{5 0}$ & 030 & 19.73 & 087 & 58.78 & 117 & 39.00 \\
\hline Total & 152 & 100 & 148 & 100 & 300 & 100.00 \\
\hline
\end{tabular}

Table.5 Coefficient correlation between personal and socio-economic variable with nutritional status of primary school children

\begin{tabular}{|l|c|}
\hline \multicolumn{1}{|c|}{ Personal and socio-economic variable } & 'r' value \\
\hline Age & $0.081^{\mathrm{NS}}$ \\
\hline Sex & $-0.023^{\mathrm{NS}}$ \\
\hline Size of family & $0.089^{\mathrm{NS}}$ \\
\hline Education of mother & $0.167^{* *}$ \\
\hline Occupation of mother & $0.085^{\mathrm{NS}}$ \\
\hline Education of father & $0.123^{*}$ \\
\hline Occupation of father & $0.117^{*}$ \\
\hline Annual income of family & $0.185^{* *}$ \\
\hline ** = Correlation is significant at the $\mathbf{0 . 0 1}$ level. \\
\hline * = Correlation is significant at the $\mathbf{0 . 0 5}$ level. \\
\hline \\
NS = Not significance
\end{tabular}


The data from the Table 3 shows that the majority ( 80.00 per cent) of respondents were having height between 100 and $140 \mathrm{~cm}$, whereas 19.33 per cent respondents having height more than $140 \mathrm{~cm}$ and rest of the respondents 0.67 per cent were having the height less than $100 \mathrm{~cm}$.

The data presented in Table 4 depicts that the majority (86.66 per cent) of respondents were having weight between 15 to $30 \mathrm{~kg}$, whereas 12.67 per cent respondents having weight more than $30 \mathrm{~kg}$ and rest of the respondents 0.67 per cent were having the weight less than $15 \mathrm{~kg}$.

It is evident from the data that 67.33 per cent of the children were having mid upper arm circumference between $15-20 \mathrm{~cm}, 20.33$ per cent of the children were having mid upper arm circumference less than $15 \mathrm{~cm}$ and 12.34 per cent of children were having mid upper arm circumference above $20 \mathrm{~cm}$.

Majority (88.34 per) cent of the children having the chest circumference between 50 to $70 \mathrm{~cm}, 11.33$ per cent followed by having chest circumference below $50 \mathrm{~cm}$ and very few 0.33 per cent of the children were more than $70 \mathrm{~cm}$ chest circumference.

59.67 percent having the head circumference between 45 to $50 \mathrm{~cm}$ and 39 per cent of children head circumference was more than $50 \mathrm{~cm}$ and very few 1.33 per cent were having below $45 \mathrm{~cm}$ head circumference.

Data presented in Table 5 shows that annual income of family and education of mother had positively highly significant relationship with nutritional status of primary school children. Education of father and occupation of father had positively significant relationship. Age, sex, size of family and occupation of mother had non-significant relationship with nutritional status of primary school children.
In conclusion the findings of study in Deodar Taluka of Banaskantha District showed that parents of the majority of children having low to medium annual family income so their socio-economic status was low. They were undernourished or had moderate level of malnutrition. From the above findings, it can be concluded that the socio-economic status of primary school children and their family in Deodar Taluka is still low and lacking some of the basic facilities.

The above findings also reveal that deficit in both height and weight suggests chronic deficiency of nutrients in the diet pointing to under nutrition. Maximum of the primary school children were low weight or moderately malnourished. Study is indicative that nutritional status was correlated with economic status and had significant relationship with education of mother, education and occupation of father and annual income of family. Thus, the result of present study stress on empowering women with education, economic independence and decision making in child rearing followed by education on nutrition and health care, thereby achieving or improving in the nutritional status of primary school children.

\section{Implication}

Study findings can be used for creating awareness among mothers of school children and training Programmes can be organized to demonstrate nutritive recipes for school children.

\section{References}

Chamar, N. (2015). Assessment of nutritional status of school children: Their influence. M.Sc. (Home science). Thesis (Unpublished). Sardar krushi nagar dantiwada Agricultural University, Gujarat. 
Indian Academy of Pediatrics (1990). Classification of Protein Calorie Malnutrition. Indian Pediatric.9 (4):360-368.

John, S.; Lewis, A.; Kliegman, R. M.; Arvin R. E, and Nelson A. M. (2000). In Behrman Nutrition, malnutrition Textbook of Pediatrics, 16th ed. W.B. Saunders. 1692. Healthy food guide for Egyptian family, Nutrition Institutite, Egypt, 2.

Kumawat, R.; Acharya, R.; Sharma, G.; Sethia, R.; Shekhawat, K. and Meena, R.; (2016).A descriptive cross-sectional study to assess prevalence of malnutrition in school children 6-14 years of age in rural and urban area of Bikaner, Rajasthan, India. Intentional Journal of Community Medical Public Health. 3(5):1079-1083.

NNMB (2000). Diet and Nutritional Status of Rural Population: NNMB Technical
Report No. 21. National Institute of Nutrition, Indian Council of Medical Research, Hyderabad, India.

Rahaman et al., (2019) Nutritional status of primary school children in different parts of India: A review

Sati, V. and Dahiya, S. (2012). Nutritional Assessment of Rural School-Going Children (7-9 Years) of Hisar District, Haryana. 1:363. doi: 10.4172/scientific reports.363

Singh, R.; Bhatnagar, M.; Mathur, B.; Singh. H. and Kumar, Y. (2009). Comparative study of nutritional status of primary school children in urban area of Jhansi. Indian Journal of Community Health. 21(1, 2):56-60.

WHO (2007). Physical status: the use and interpretation of anthropometry. Report of a WHO Expert Committee, Geneva, World Health Organisation.

\section{How to cite this article:}

Nayna P. Raval, I. N. Patel, Kundan Joshi and Surabhi Singh. 2020. Nutritional Status of School Children (6-12 years) in Deodar Taluka-Gujarat. Int.J.Curr.Microbiol.App.Sci. 9(08): 3658-3665. doi: https://doi.org/10.20546/ijcmas.2020.908.422 